\title{
Rectus Sheath Hematoma: Case Report
}

\author{
Rektus Kilıfi Hematomu: Olgu Sunumu
}

\author{
Murat Eroğlu' ${ }^{1}$, Ali Kağan Coşkun ${ }^{2}$ \\ ${ }^{1}$ Mareşal Çakmak Asker Hastanesi, Acil Servis, Erzurum \\ ${ }^{2}$ Gülhane Askeri Tip Fakültesi, Genel Cerrahi Anabilim Dalı, Ankara
}

\begin{abstract}
Rectus sheath hematoma is an uncommon cause of abdominal pains. It usually occurs spontaneously or after trauma. In diagnosis, clinical, laboratory and radiologic data are used. Ultrasonography and computerized tomography allow correct diagnosis of rectus sheath hematoma. The incorrect diagnosis can cause negative laporotomies with high rate of mortality and morbidity. The conservative treatment method should be preferred in hemodynamically stable patients.
\end{abstract}

Key words: Abdominal pain, Rectus sheath, Trauma, Conservative treatment.

\section{ÖZET}

Rektus kılıfı hematomu akut abdominal ağrıların yaygın olmayan bir nedenidir. Genellikle spontan veya travma sonrasında oluşur. Tanısında klinik, laboratuar ve radyolojik veriler kullanılır. Ultrasonografi ve bilgisayarlı tomografi rektus kılıfi hematomunun doğru tanısının konulmasına olanak sağlar. Yanlış tanılar, artmış mortalite ve morbidite ile birlikte gereksiz negatif laparotomilere neden olabilir. Konservatif tedavi hemodinamik olarak stabil hastalarda tercih edilmesi gereken yöntemdir.

Anahtar kelimeler: Karın ağrısı, Rektus kılıfı, Travma, Konservatif tedavi.

Iletişim Adresi ve Sorumlu Yazar:

Murat EROĞLU

Mareşal Çakmak Asker Hastanesi, 25100 Erzurum - Türkiye

E-mail:drmeroglu@yahoo.com

Telefon: 05057891791 


\section{INTRODUCTION}

Rectus sheath hematoma is well-described, however it is an uncommon cause of abdominal pains ${ }^{[1]}$. Collection of blood inside the sheath of rectus abdominis may occur as secondary to rupture of epigastric vessels or muscle tears [2]. It usually occurs spontaneously or after trauma. The branches of the inferior epigastric artery being connected tightly while passing through the rectus muscles and body movements creates cutter and predatory power in place of the connection of arterial branches ${ }^{[3]}$. Other predisposing factors are the increasing pressure of intraabdominal depending on the blood dyscrasia ${ }^{[4]}$, previous abdominal surgeries, anticoagulant drug use ${ }^{[5]}$, applied drugs under skin ${ }^{[6]}$, cough ${ }^{[7]}$, strech ${ }^{[2]}$, or pregnancy ${ }^{[8]}$. The most common feature encountered in application of patients is painful lower abdominal mass which not exceeding midline. This painful mass can imitate a intraperitoneal mass with the features of a acute abdomen ${ }^{[9]}$. Rectus sheath hematomas are usually formed in lower quadrant of abdominal wall ${ }^{[10]}$. Clinical, laboratory and radiologic data are used in diagnosis of rectus sheath hematoma. Ultrasonography (USG) and computerized tomography (CT) are considerably succesful in the differentiation of other intraabdominal pathology and to diagnose. Correct diagnosis is compulsory in order to avoid unnecessary laparotomy ${ }^{[11]}$.

In this article, we presented a case of rectus hematoma detected after exercise.

\section{CASE REPORT}

A 21 year old man applied our emergency service with the complaint of severe stomach ache. It was understood that patient has pain increasing in severity that started sudden at the right side of the abdomen while exercising during taking pullup, nausea and vomiting. In patients physical examination it was found that blood pressure: $130 / 70 \mathrm{mmHg}$, fever: $36.5^{\circ} \mathrm{C}$, pulse: $72 / \mathrm{min}$, respiration number: $14 / \mathrm{min}$. Listened intestines sounds were normal. Being most in right upper quadrant in abdomen, prevalent sensibility and prevalent muscular defense was detected with treatment. Rebound was detected. Any mass findins were not detected in abdomen. Other system treatments were normal. Hemoglobin: $15.4 \mathrm{~g} /$ dL, Htc: $46.3 \%$, Platelet: 374.000/ $\mu \mathrm{L}$, aPTT: $22.4 \mathrm{sec}$, PT: $12.5 \mathrm{sec}$ and INR: 1.07. Hematoma which boundaries could not be determined clearly was detected in USG in right rectus muscle (Figure 1). In computerized tomography (CT), approximately $1 \times 2 \mathrm{~cm}$ sized high-density hematoma was seen inside right rectus muscle (Figure 2). The patient was admitted to the hospital. Patient's complaints were reduced by the bed rest and analgesic medication. Any decrease in hemoglobin level was not determined in monitoring. It is detected that hematoma was completely resolved in USG control that made a month after discharge.

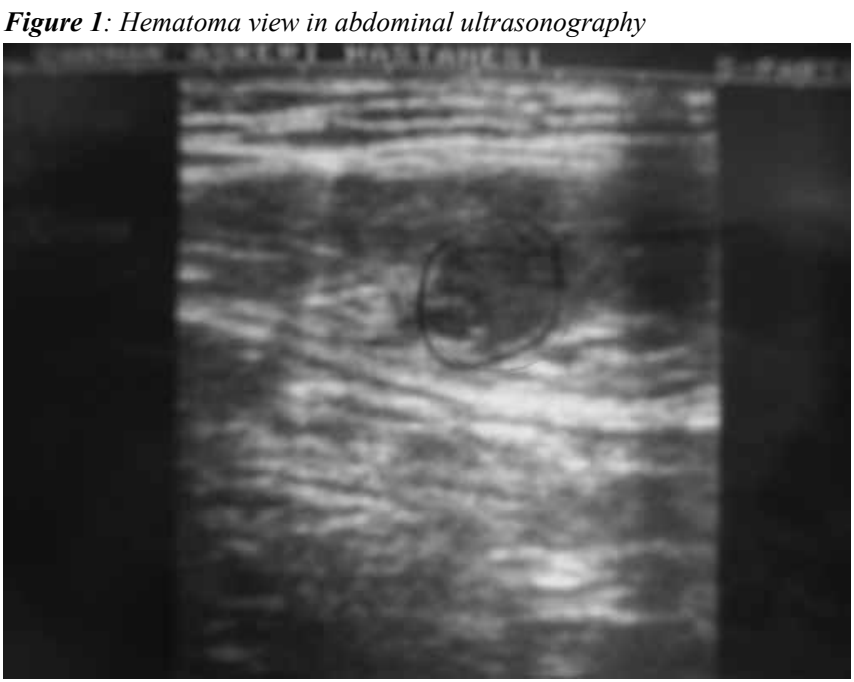

Figure 2: Hematoma view inside the right rectus sheath in abdominal computerized tomography

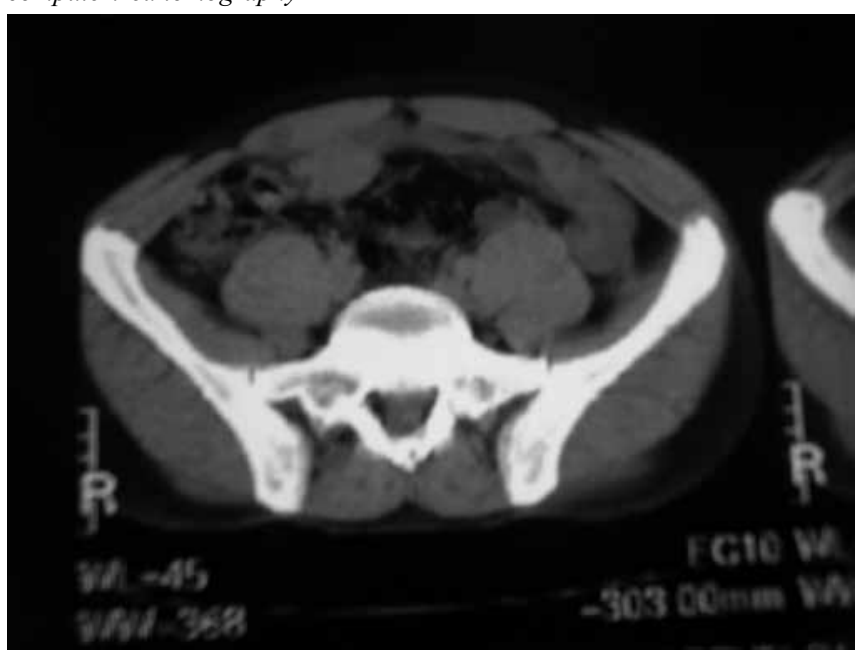

\section{DISCUSSION}

Rectus sheath hematoma is rare but it is an important disease that cause abdominal pain. Being considered in differential diagnosis with using appropriate imaging techniques provides to make the diagnosis and treatment of rectus sheath hematoma in series ${ }^{[12]}$. Wrong diagnosis can cause unnecessary negative laparotomies with increased mortality and morbidity ${ }^{[13]}$. USG, CT and MRI are widely used in diagnosis. CT is more superior than USG about evaluation of localization, extension and size of hematoma ${ }^{[14]}$. In our case, rectus hematoma was thought starting with the patient history and treatment findings. Because the hematoma was too small, the borders and size of hematoma could not be determined exactly in USG. After USG, the size of hematoma was determined more clearly with CT analysis.

Conservative treatment method should be preferred in patients with hemodynamically stable and have no expanding hematoma ${ }^{[15]}$. In our case, the conservative treatment was sufficient. In the case which conservative treatment failed surgical approach can be preferred but the rate of mortality 
is high. Coil embolization and percutaneous arterial embolization are alternative treatments in high-risk patients that difficult to heal with conservative treatment ${ }^{[16]}$.

The most important factor in diagnosis of rectus sheath hematoma is to be aware of its existence. Differential diagnosis should also be considered in cases applied with acute abdominal pain. USG should be preferred at first in suspected case because of its simple and inexpensive examination, but CT is more useful for a definite diagnosis.. Early and true diagnosis is important in success of conservative treatment and to prevent unnecessary surgical attempts and its complications.

\section{REFERENCES}

1. Verhagen HJ, Tolenaar PL, Sybrandy R. Haematoma of the rectus abdominis muscle. Eur J Surg 1993;159:335-8.

2. Sharma H, Shekhawat NS, Bhandari S, Memon B, Memon MA. Rectus sheath haematoma: a rare presentation of non-contact strenuous exercises. Br J Sports Med 2007;41:688-90

3. Holmes SJ, Yale SH, Mazza JJ. Rectus Sheath Hematoma as a Cause of Acute Abdominal Pain. American Family Physicians 2001;64:1681-2.

4. Wegener ME, Ghani A. Rectus sheath hematomas in hematological disorders. Am Surg 1994; 60:424-6.

5. Donaldson J, Knowles CH, Clark SK, Renfrew I, Lobo MD. Rectus Sheath Haematoma Associated with Low Molecular Weight Heparin: A Case Series. Ann R Coll Surg Engl 2007;89: 309-12.

6. Denard PJ, Fetter JC, Zacharski LR. Rectus sheath hematoma complicating low-molecular weight heparin therapy. Int J Lab Hematol 2007;29:190-4.

7. Papadimitropoulos K, Condilis N, Philippou P, Birbilis A. Rectus sheath haematoma. report of two cases. Ann Ital Chir 2007;78:447-50.

8. Deb S, Hoo P, Chilaka V. Rectus sheath haematoma in pregnancy: a clinical challenge. J. Obstet Gynaecol 2006;26:822-3.

9. Siu WT, Tang CN, Law BK, Chau CH, Li MKW. Spontaneous rectus sheath hematoma. J Can Chir 2003;46: 390-1.

10. Maharaj D, Ramdass M, Teelucksingh S, Perry A, Naraynsingh V. Rectus sheath haematoma: a new set of diagnostic features. Postgrad Med J 2002;78:755-6.

11. Gallego AM, Aguayo JL, Flores B, at al. Ultrasonography and computed tomography reduce unnecessary surgery in abdominal rectus sheath haematoma. $\mathrm{Br} \mathrm{J}$ Surg 1997;84:1295-7

12. Cherry WB, Mueller PS. Rectus sheath hematoma: review of 126 cases at a single institution. Medicine (Baltimore) 2006; 85:105-10.

13. Lohle PN, Puylaert JB, Coerkamp EG, Hermans ET. Nonpalpable rectus sheath hematoma clinically masquerading as appendicitis: US and CT diagnosis. Abdom Imaging 1995;20:152-4.

14. Berná JD, Garcia-Medina V, Guirao J, Garcia-Medina J. Rectus sheath hematoma: diagnostic classification by CT. Abdom Imaging 1996;21:62-4.

15. George P, Phillip NP, Pawar B, Solomon L. Inferior vena cava thrombosis following rectus sheath haematoma. Singapore Med J 2008; 49:50-2.

16. Wong JHM, Man Ng SS, Ho SSM, Lee JFY. Transcatheter Arterial Embolization of Spontaneous Rectus Sheath Haematoma in a Chinese Woman. Asian J Surg 2008; 31:36-9. 